ScIDice

\section{Knowledge, Attitude, and Practice Survey Among Endodontic Postgraduate Students Towards Scaffolds in Regenerative Endodontics}

Research Article

Harish Selvaraj ${ }^{1}$, Deepak Selvam²

${ }^{1}$ Postgraduate Student, Department of Conservative Dentistry and Endodontics, Saveetha Dental College and Hospital, Saveetha Institute of Medical and Technical Sciences, Saveetha University, Chennai 600077, Tamil Nadu, India.

${ }^{2}$ Senior Lecturer, Department of Conservative Dentistry and Endodontics, Saveetha Dental College and Hospital, Saveetha Institute of Medical and Technical Sciences, Saveetha University, Chennai 600077, Tamil Nadu, India.

\title{
Abstract
}

Background: Regenerative endodontics aims to regenerate the pulp-dentine complex which got damaged by infection, trauma or developmental anomaly of immature permanent teeth with necrotic pulp. Regenerative endodontic procedures include scaffolds, growth factors and stem cells. Adequate knowledge about each scaffold, their clinical applications and benefits are essential for clinical success in regenerative endodontic procedures.

Aim: The aim of the present study is to investigate the knowledge, attitude and practice on scaffolds used in regenerative endodontic procedures among the endodontic postgraduate students of India.

Methodology: A cross-sectional questionnaire based study was conducted in 2020 among Endodontic postgraduate students of India. Survey questionnaires were prepared, using Google forms and it was distributed randomly to 236 Endodontic postgraduate students. The obtained results were statistically analysed using SPSS and the graphs were plotted.

Results: All the postgraduate students have a general knowledge about what scaffolds are and their uses, however third year endodontic postgraduate students have good knowledge and experience in using scaffolds in their clinical practice compared to first and second year endodontic postgraduate students.

Conclusion: Good knowledge and positive attitude towards the use of scaffolds were observed among postgraduate students. However, since most of the first and second year postgraduate students have not started using scaffolds in their practice, a need for clinical training programmes would be efficient.

Keywords: Scaffolds; Stem Cells; Growth Factors; Regenerative Endodontics.

\section{Introduction}

Dental pulp tissue is a highly innervated and strongly vascularized tissue [1]. Pulp revascularization re-establishes the vascularity in the root canal system. It induces angiogenesis in the endodontically treated root canal. Pulp regeneration involves pulp revascularization and restoration of functional odontoblasts and nerve fibers [2]. Morphogens, progenitor or stem cells and the extracellular matrix (ECM) scaffold are very important for regeneration.

Traditional treatment for immature permanent teeth with necrotic pulp or teeth with apical periodontitis is by calcium hydroxide which induces apical hard tissue barrier formation or apical MTA plug before root canal filling [3, 4]. Increased risk of root fracture is seen in immature permanent teeth with prolonged calcium hydroxide dressing [5]. An apexification procedure does not have the potential to restore the vitality of damaged tissue in the root canal space and promote root maturation (thickening of the root canal walls and/or apical closure) of immature permanent teeth with necrotic pulp. So the revascularization procedure was introduced in endodontics for the management of immature permanent teeth with apical periodontitis or sinus tract $[5,6]$.

The term revascularization was replaced by revitalization as blood vessels along with both hard and soft tissues were regenerated [7]. 'Regenerative endodontics' was a term adopted by American As-

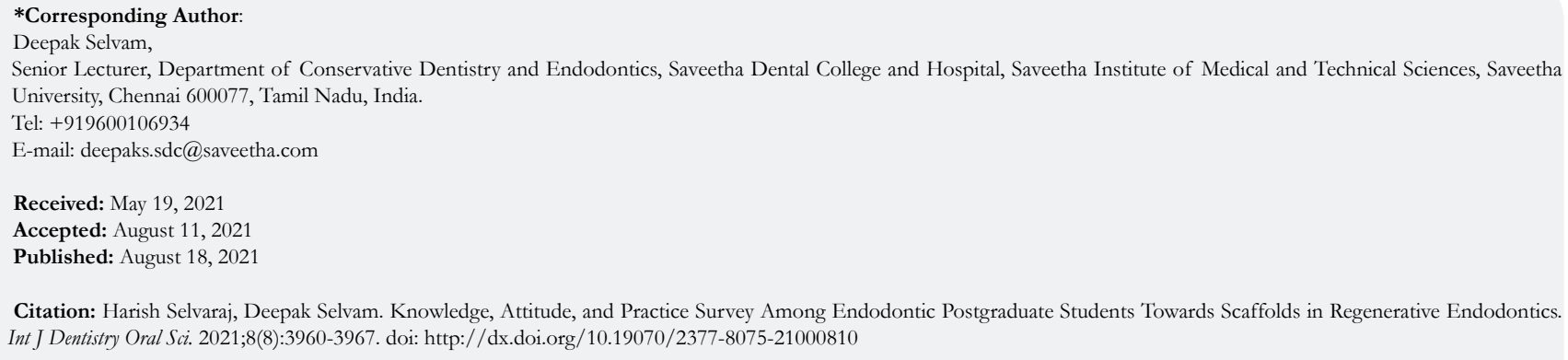

Citation: Harish Selvaraj, Deepak Selvam. Knowledge, Attitude, and Practice Survey Among Endodontic Postgraduate Students Towards Scaffolds in Regenerative Endodontics. Int J Dentistry Oral Sci. 2021;8(8):3960-3967. doi: http://dx.doi.org/10.19070/2377-8075-21000810

Copyright: Deepak Selvam 2021. This is an open-access article distributed under the terms of the Creative Commons Attribution License, which permits unrestricted use, distribution and reproduction in any medium, provided the original author and source are credited. 
sociation of Endodontists in the year 2007. It relates to the triad of tissue engineering, stem cells, biomimetic scaffolds, and bioactive growth factors in the root canal space to regenerate the pulp tissue damaged by infection, trauma or developmental anomalies $[7,8]$.

Nygaard-Ostby was a pioneer in regenerative endodontics. Nygaard -Ostby \& Hjortdal in 1971 induced bleeding from the periapical tissues into the debrided root canal space of the teeth, which had a partial root filling. Histological examination of teeth extracted after 9 days to 3 years revealed that fibrous connective tissue and cellular cementum were formed in the apical canal space of teeth originally containing vital pulp. But in teeth with necrotic pulp there wasn't any formation of repair tissue in the apical canal space [9].

Regenerative endodontics can be defined as "biologically based procedures designed to replace damaged tooth structures, including dentine and root structures, as well as cells of the pulp -dentine complex" [10]. Hence, regenerative endodontics aims to regenerate the pulp-dentine complex which was damaged by infection, trauma or developmental anomaly of immature permanent teeth with necrotic pulp.

Regenerative endodontic procedures include scaffolds, growth factors and stem cells. Scaffolds are three-dimensional (3D) porous solid biomaterials designed which provide a spatially correct position of cell location, they promote cell-biomaterial interactions, cell adhesion, and ECM deposition, permit sufficient transport of gases, nutrients and regulatory factors to allow cell survival, proliferation and differentiation, biodegrade at a controllable rate that approximates the rate of tissue regeneration and provoke a minimal degree of inflammation or toxicity in vivo.

Growth factors regulate both transplanted and endogenous cells in dental pulp-dentin regeneration. They are polypeptides or proteins that bind to receptors on target cell surfaces. Stem cells are undifferentiated embryonic or adult cells that divide indefinitely. They have the ability to divide and produce new stem cells, as well as differentiate through a specific molecular pathway. Adequate knowledge about each scaffold, their clinical applications and benefits are essential for clinical success in regenerative endodontic procedures.

Hence, this cross sectional study aims to assess the knowledge and opinion towards scaffolds used in regenerative endodontic procedures among the endodontic postgraduate students of India. Previously our team has a rich experience in working on various research projects across multiple disciplines [11 - 25]. Now the growing trend in this area motivated us to pursue this project.

\section{Materials and Methods}

Endodontic postgraduate students of India were asked to fill an online survey. The students participated out of their own free will. A total of three groups participated in the study. A total of 236 students participated in the study out of which 90 students belonged to first year, 84 students belonged to second year and 62 students belonged to third year. The study was approved by the Institutional Review Board at Saveetha Institute of Medical and Technical Sciences.

\section{Data Collection:}

Each student was asked to fill an online survey via Google forms. The exclusion criteria was that unwillingness to participate in the survey and the students belonging to other courses. The questionnaire consisted of 2 questions on demographics, 6 questions on knowledge, 5 questions on attitude and 5 questions based on practice.

\section{Statistical Analysis:}

The statistical analysis of data was done using IBM SPSS 1.0.0. 1406 64-bit edition software for Windows 10. Pearson chi-square test was used to find if there was an association between the variables.

\section{Results \& Discussion}

236 complete responses were received from endodontic postgraduate students in India. The overall responses of the survey are given in Table 1.

Results of Figure 1. shows the students' knowledge on the procedures included in Regenerative Endodontics. $93.3 \%$ of the first year, $100 \%$ of second and third year students opted for all the above which included Scaffolds, growth factors and stem cells. Figure 2. shows students knowledge on what scaffolds are, in which $97.8 \%$ of first year and $100 \%$ of second and third year students opted for three-dimensional (3D) porous solid biomaterials used in tissue regeneration. Figure 3. shows how students gathered information about scaffolds in which the majority of first year students gathered by attending conferences and CDE programmes $(53.3 \%)$, second year students by reading articles $(78.6 \%)$ and third year students had it in their part of postgraduate curriculum $(90.3 \%)$. Figure 4 . shows students' knowledge about the applications of scaffolds in regenerative endodontic procedures in which majority of first $(86.7 \%)$, second $(95.2 \%)$, third $(100 \%)$ opted for all the options mentioned, that is to provide structure to a developing tissue, secrete extracellular matrix, allow cells to adhere, proliferate, differentiate. When the students were asked about the type of scaffold which would be the most effective $93.3 \%$ first year, $57.1 \%$ of second year and $100 \%$ of third years felt that both natural and synthetic scaffolds are effective (Fig.5). Majority of the first year students $49.9 \%$ were unsure about if the porosity and size of pores influenced the success rate, $88.1 \%$ of second year and $100 \%$ of third year students felt that the porosity and size of the pores plays a role in its success rate (Fig. 6). Most of the first (93.3\%) and second $(88.1 \%)$ year students had not used any types of scaffolds in their clinical practice and majority of students from third year (100\%) have used scaffolds (Fig.7). The most commonly preferred scaffold for the revascularization of necrotic immature permanent teeth with open apex by first year students was platelet- rich plasma (61.9\%), platelet- rich fibrin was opted by second year students $(45.2 \%)$ and third year students (90.3\%) (Fig.8).

For management of large periapical lesions majority of first year students $(51.1 \%)$ and third year students $(83.9 \%)$ preferred platelet- rich fibrin and $81 \%$ of second year students preferred a combination of platelet concentrate along with bone grafts (Fig.9). 
Table 1. Questionnaires included in this survey and their responses.

\begin{tabular}{|c|c|c|c|c|}
\hline Questionnaires & First year & Second year & Third Year & p-value $(<0.05$; statistically significant) \\
\hline $\begin{array}{l}\text { Which of the following are } \\
\text { included in regenerative } \\
\text { endodontic procedures? }\end{array}$ & $\begin{array}{c}\text { Scaffolds- } 6(6.7 \%) \\
\text { Growth factors- } 0 \\
\text { Stem cells- } 0 \\
\text { All of the above - } 84(93.3 \%)\end{array}$ & $\begin{array}{c}\text { Scaffolds- } 0 \\
\text { Growth factors- } 0 \\
\text { Stem cells- } 0 \\
\text { All of the above - } 84(100 \%)\end{array}$ & $\begin{array}{c}\text { Scaffolds- } 0 \\
\text { Growth factors- } 0 \\
\text { Stem cells- } 0 \\
\text { All of the above }-62(100 \%)\end{array}$ & $\begin{array}{c}\text { Pearson Chi-Square Value }=9.987 \\
\mathrm{df}=2 \\
\mathrm{p} \text { value }=.007\end{array}$ \\
\hline Scaffolds are & $\begin{array}{l}\text { Three-dimensional }(3 \mathrm{D}) \text { porous solid } \\
\text { biomaterials used in tissue regenera- } \\
\quad \text { tion- } 88(97.8 \%) \\
\text { Dental Restorative materials- } 2(2.2 \%)\end{array}$ & $\begin{array}{c}\text { Three-dimensional (3D) porous solid } \\
\text { biomaterials used in tissue regenera- } \\
\text { tion- } 84(100 \%) \\
\text { Dental Restorative materials- } 0\end{array}$ & $\begin{array}{c}\text { Three-dimensional (3D) porous solid } \\
\text { biomaterials used in tissue regenera- } \\
\text { tion-62(100\%) } \\
\text { Dental Restorative materials-0 }\end{array}$ & $\begin{array}{c}\text { Pearson Chi-Square Value }=3.272 \\
\mathrm{df}=2 \\
\mathrm{p} \text { value }=.195\end{array}$ \\
\hline $\begin{array}{l}\text { How did you gather infor- } \\
\text { mation about scaffolds in } \\
\text { regenerative endodontics? }\end{array}$ & $\begin{array}{c}\text { By reading articles- } 26(28.9 \%) \\
\text { By attending seminars- } 10(11.1 \%) \\
\text { By attending conferences and CDE } \\
\text { programmes- } 48(53.3 \%) \\
\text { In a part of PG curriculum- } 4(4.4 \%) \\
\text { Others- } 2(2.2 \%)\end{array}$ & $\begin{array}{c}\text { By reading articles- } 66(78.6) \\
\text { By attending seminars- } 2(2.4 \%) \\
\text { By attending conferences and } \mathrm{CDE} \\
\text { programmes- } 6(7.1 \%) \\
\text { In a part of PG curriculum- } 8(9.5 \%) \\
\text { Others- } 2(2.4 \%)\end{array}$ & $\begin{array}{c}\text { By reading articles- } 6(9.7 \%) \\
\text { By attending seminars- } 0 \\
\text { By attending conferences and } \mathrm{CDE} \\
\text { programmes- } 0 \\
\text { In a part of PG curriculum- } 56(90.3) \\
\text { Others- } 0\end{array}$ & $\begin{array}{c}\text { Pearson Chi-Square Value }=229.147 \\
\mathrm{df}=8 \\
\mathrm{p} \text { value }=.000\end{array}$ \\
\hline $\begin{array}{l}\text { What do you think are the } \\
\text { uses of a scaffold? }\end{array}$ & $\begin{array}{c}\text { Provide structure to a developing } \\
\text { tissue- } 0 \\
\text { Secrete extracellular matrix- } 0 \\
\text { Allow cells to adhere, proliferate, differen } \\
\text { tiate- } 12(13.3 \%) \\
\text { All of the above- } 78(86.7)\end{array}$ & $\begin{array}{l}\text { Provide structure to a developing tis- } \\
\text { sue- } 4(4.8 \%) \\
\text { Secrete extracellular matrix- } 0 \\
\text { Allow cells to adhere, } \\
\text { proliferate, differentiate- } 0 \\
\text { All of the above- } 80(95.2 \%)\end{array}$ & $\begin{array}{c}\text { Provide structure to a developing } \\
\text { tissue- } 0 \\
\text { Secrete extracellular matrix- } 0 \\
\text { Allow cells to adhere, } \\
\text { proliferate, differentiate- } 0 \\
\text { All of the above- } 62(100 \%)\end{array}$ & $\begin{array}{c}\text { Pearson Chi-Square Value }=27.462 \\
\mathrm{df}=4 \\
\mathrm{p} \text { value }=.000\end{array}$ \\
\hline $\begin{array}{l}\text { Which type of scaffolds do } \\
\text { you think are effective in } \\
\text { regenerative endodontics? }\end{array}$ & $\begin{array}{c}\text { Natural- } 4(4.4 \%) \\
\text { Synthetic-2(2.2\%) } \\
\text { Both- } 84(93.3 \%)\end{array}$ & $\begin{array}{l}\text { Natural-32(38.1\%) } \\
\text { Synthetic-4(4.8\%) } \\
\text { Both-48(57.1\%) }\end{array}$ & $\begin{array}{c}\text { Natural-0 } \\
\text { Synthetic-0 } \\
\text { Both-62(100\%) }\end{array}$ & $\begin{array}{c}\text { Pearson Chi-Square Value }=58.484 \\
\mathrm{df}=4 \\
\mathrm{p} \text { value }=.000\end{array}$ \\
\hline $\begin{array}{l}\text { Do you think the porosity } \\
\text { and size of the pores of the } \\
\text { scaffold material play a role in } \\
\text { its success rate? }\end{array}$ & $\begin{array}{c}\text { Yes-40(44.4\%) } \\
\text { No-6(6.7\%) } \\
\text { Unsure-44(49.9\%) }\end{array}$ & $\begin{array}{c}\text { Yes-74(88.1\%) } \\
\text { No-0 } \\
\text { Unsure-10(17.2\%) }\end{array}$ & $\begin{array}{c}\text { Yes-58 }(93.5 \%) \\
\text { No-0 } \\
\text { Unsure-4(6.5\%) }\end{array}$ & $\begin{array}{c}\text { Pearson Chi-Square Value }=61.443 \\
\mathrm{df}=4 \\
\mathrm{p} \text { value }=.000\end{array}$ \\
\hline $\begin{array}{l}\text { Have you used any kind of } \\
\text { scaffolds for regenerative } \\
\text { endodontic procedures? }\end{array}$ & $\begin{array}{c}\text { Yes-6(6.7\%) } \\
\text { No-84(93.3\%) }\end{array}$ & $\begin{array}{l}\text { Yes-10 }(11.9 \%) \\
\text { No-74(88.1\%) }\end{array}$ & $\begin{array}{l}\text { Yes- } 62(100 \%) \\
\text { No-0 }\end{array}$ & $\begin{array}{c}\text { Pearson Chi-Square Value }=170.879 \\
\mathrm{df}=2 \\
\mathrm{p} \text { value }=.000\end{array}$ \\
\hline $\begin{array}{l}\text { Which scaffold would you } \\
\text { prefer for revascularization of } \\
\text { necrotic immature permanent } \\
\text { teeth with an open apex? }\end{array}$ & $\begin{array}{c}\text { Platelet-rich plasma (PRP)-52(61.9\%) } \\
\text { Platelet-rich fibrin (PRF)- } \\
\text { Polyglycolic acid (PGA)-10(11.1\% } \\
\text { Bioactive ceramics-4(4.4\%) } \\
\text { Concentrated growth factor (CGF)- } \\
2(2.2 \%) \\
\text { Platelet-rich in growth factor (PRGF)- } \\
14(15.6 \%) \\
\text { Collaplug-4(4.4\%) } \\
\text { Injectable hydrogel (Puramatrix)-2(2.2\%) }\end{array}$ & $\begin{array}{c}\text { Platelet-rich plasma (PRP)-32(38.1\%) } \\
\text { Platelet-rich fibrin (PRF)-38(45.2\%) } \\
\text { Polyglycolic acid (PGA)-2(2.4\%) } \\
\text { Bioactive ceramics-0 } \\
\text { Concentrated growth factor (CGF)- } \\
\text { 6(7.1\%) } \\
\text { Platelet-rich in growth factor (PRGF)- } \\
2(2.4 \%) \\
\text { Collaplug-0 } \\
\text { Injectable hydrogel (Puramatrix)-4(4.8\%) }\end{array}$ & $\begin{array}{c}\text { Platelet-rich plasma (PRP)- } 0 \\
\text { Platelet-rich fibrin (PRF)-56(90.3\%) } \\
\text { Polyglycolic acid (PGA)-0 } \\
\text { Bioactive ceramics-0 } \\
\text { Concentrated growth factor (CGF)-0 } \\
\text { Platelet-rich in growth factor } \\
\text { (PRGF)-6(9.7\%) } \\
\text { Collaplug-0 } \\
\text { Injectable hydrogel (Puramatrix)-0 }\end{array}$ & $\begin{array}{c}\text { Pearson Chi-Square Value }=123.395 \\
\begin{array}{c}\mathrm{df}=14 \\
\mathrm{p} \text { value }=.000\end{array}\end{array}$ \\
\hline $\begin{array}{l}\text { Which scaffold would you } \\
\text { prefer for the management of } \\
\text { a large periapical lesion? }\end{array}$ & $\begin{array}{c}\text { Platelet-rich plasma (PRP)- } 6(6.7 \%) \\
\text { Concentrated growth factor (CGF)- } \\
8(8.9 \%) \\
\text { Plasma-rich in growth factor (PRGF)- } \\
12(13.3 \%) \\
\text { Platelet-rich Fibrin (PRF)- } 46(51.1 \%) \\
\text { Combination of platelet concentrate } \\
\text { along with bone grafts-18(20\%) } \\
\text { Others-0 }\end{array}$ & $\begin{array}{c}\text { Platelet-rich plasma (PRP)-0 } \\
\text { Concentrated growth factor (CGF)- } \\
6(7.1 \%) \\
\text { Plasma-rich in growth factor (PRGF)- } \\
2(2.4 \%) \\
\text { Platelet-rich Fibrin (PRF)- } 6(7.1 \%) \\
\text { Combination of platelet concentrate } \\
\text { along with bone grafts-68(81\%) } \\
\text { Others- } 2(2.4 \%)\end{array}$ & $\begin{array}{c}\text { Platelet-rich plasma (PRP)- } \\
\text { Concentrated growth factor (CGF)- } \\
2(3.2 \%) \\
\text { Plasma-rich in growth factor } \\
\text { (PRGF)-0 } \\
\text { Platelet-rich Fibrin (PRF)- } 52(83.9 \%) \\
\text { Combination of platelet concentrate } \\
\text { along with bone grafts- } 4(6.5 \%) \\
\text { Others-0 }\end{array}$ & $\begin{array}{c}\text { Pearson Chi-Square Value }=137.179 \\
\mathrm{df}=10 \\
\mathrm{p} \text { value }=.000\end{array}$ \\
\hline $\begin{array}{l}\text { Which scaffold would you } \\
\text { prefer for the management } \\
\text { of periodontic-endodontic } \\
\text { lesions? }\end{array}$ & $\begin{array}{c}\text { Platelet-rich fibrin (PRF)-52(57.8\%) } \\
\text { Concentrated Growth Factor (CGF)- } \\
14(15.6 \%) \\
\text { Platelet-rich plasma (PRP)-6(6.7\%) } \\
\text { Platelet-rich in growth factor (PRGF)- } \\
4(4.4 \%) \\
\text { Combination of platelet concentrate } \\
\text { along with bone grafts-14(15.6\%) } \\
\text { Others- } 0\end{array}$ & $\begin{array}{c}\text { Platelet-rich fibrin (PRF)- } 40(47.6 \%) \\
\text { Concentrated Growth Factor (CGF)- } \\
6(7.1 \%) \\
\text { Platelet-rich plasma (PRP)- } 4(4.8 \%) \\
\text { Platelet-rich in growth factor (PRGF)- } \\
4(4.8 \%) \\
\text { Combination of platelet concentrate } \\
\text { along with bone grafts- } 26(31 \%) \\
\text { Others- } 4(4.8 \%)\end{array}$ & $\begin{array}{c}\text { Platelet-rich fibrin (PRF)-8 }(12.9 \%) \\
\text { Concentrated Growth Factor } \\
\text { (CGF)-0 } \\
\text { Platelet-rich plasma (PRP)-0 } \\
\text { Platelet-rich in growth factor } \\
\text { (PRGF)- } 0 \\
\text { Combination of platelet concentrate } \\
\text { along with bone grafts-54(87.1\%) } \\
\text { Others-0 }\end{array}$ & $\begin{array}{c}\text { Pearson Chi-Square Value }=92.838 \\
\mathrm{df}=10 \\
\mathrm{p} \text { value }=.000\end{array}$ \\
\hline $\begin{array}{l}\text { How often do you treat } \\
\text { necrotic immature permanent } \\
\text { teeth? }\end{array}$ & $\begin{array}{c}\text { Very often-2(2.2\%) } \\
\text { Sometimes-26(28.9\%) } \\
\text { Rarely-58(64.4\%) } \\
\text { Never-4(4.4\%) }\end{array}$ & $\begin{array}{c}\text { Very often- } 4(4.8 \%) \\
\text { Sometimes- } 16(19 \%) \\
\text { Rarely-64(76.2\%) } \\
\text { Never-0 }\end{array}$ & $\begin{array}{c}\text { Very often- }-4(6.5 \%) \\
\text { Sometimes- } 58(93.5 \%) \\
\text { Rarely- } 0 \\
\text { Never- } 0 \\
\end{array}$ & $\begin{array}{c}\text { Pearson Chi-Square Value }=105.722 \\
\qquad \begin{array}{c}\mathrm{df}=6 \\
\mathrm{p} \text { value }=.000\end{array}\end{array}$ \\
\hline $\begin{array}{l}\text { Would you recommend scaf- } \\
\text { fold as a treatment for tissue } \\
\text { regeneration to your patients? }\end{array}$ & $\begin{array}{c}\text { Yes-40 }(44.4 \%) \\
\text { No-4 }(4.4 \%) \\
\text { Maybe-46(51.1\%) } \\
\end{array}$ & $\begin{array}{c}\text { Yes-18(21.4\%) } \\
\text { No-2(2.4\%) } \\
\text { Maybe-64(76.2\%) }\end{array}$ & $\begin{array}{c}\text { Yes-60 }(96.8 \%) \\
\text { No-0 } \\
\text { Maybe-2(3.2\%) } \\
\end{array}$ & $\begin{array}{c}\text { Pearson Chi-Square Value }=84.690 \\
\mathrm{df}=4 \\
\mathrm{p} \text { value }=.000\end{array}$ \\
\hline $\begin{array}{l}\text { What would you think would } \\
\text { be the attitude of the patient } \\
\text { towards tissue regenerative } \\
\text { treatment using scaffolds? }\end{array}$ & $\begin{array}{l}\text { Positive- } 8(8.9 \%) \\
\text { Negative-10(11.1\%) } \\
\text { Unsure-72(80\%) }\end{array}$ & $\begin{array}{c}\text { Positive-16(19\%) } \\
\text { Negative-2(2.4\%) } \\
\text { Unsure-66(78.6) }\end{array}$ & $\begin{array}{l}\text { Positive- } 54(87.1 \%) \\
\text { Negative-0 } \\
\text { Unsure-8 }(5.5 \%)\end{array}$ & $\begin{array}{c}\text { Pearson Chi-Square Value }=119.063 \\
\mathrm{df}=4 \\
\mathrm{p} \text { value }=.000\end{array}$ \\
\hline $\begin{array}{l}\text { Do you think the high cost } \\
\text { of scaffolds influences the } \\
\text { treatment acceptance by the } \\
\text { patient? }\end{array}$ & $\begin{array}{c}\text { Yes-32(35.6\%) } \\
\text { No-4 }(4.4 \%) \\
\text { Maybe-54(60\%) }\end{array}$ & $\begin{array}{c}\text { Yes-48(57.1) } \\
\text { No-2(2.4\%) } \\
\text { Maybe-34(40.5\%) }\end{array}$ & $\begin{array}{c}\text { Yes- } 58(93.5 \%) \\
\text { No-2 }(3.2 \%) \\
\text { Maybe-2(3.2\%) }\end{array}$ & $\begin{array}{c}\text { Pearson Chi-Square Value }=52.922 \\
\mathrm{df}=4 \\
\mathrm{p} \text { value }=.000\end{array}$ \\
\hline $\begin{array}{l}\text { Would you recommend } \\
\text { regenerative procedures over } \\
\text { dental implant therapy to your } \\
\text { patients? }\end{array}$ & $\begin{array}{l}\text { Yes-82(91.1\%) } \\
\text { No-8 }(8.9 \%)\end{array}$ & $\begin{array}{l}\text { Yes-78 }(92.9 \%) \\
\text { No-6(7.1\%) }\end{array}$ & $\begin{array}{l}\text { Yes- } 62(100 \%) \\
\text { No-0 }\end{array}$ & $\begin{array}{c}\text { Pearson Chi-Square Value }=5.540 \\
\mathrm{df}=2 \\
\mathrm{p} \text { value }=.063\end{array}$ \\
\hline $\begin{array}{l}\text { Which advantage of scaffolds } \\
\text { would make it more likely for } \\
\text { you to recommend this proce- } \\
\text { dure to your patients? }\end{array}$ & $\begin{array}{l}\text { Treatment effectiveness-24(26.7\%) } \\
\text { Safety and Reliability-64(71.1\%) } \\
\text { Would not recommend-2(2.2\%) }\end{array}$ & $\begin{array}{l}\text { Treatment effectiveness-16(19\%) } \\
\text { Safety and Reliability- } 64(76.2 \%) \\
\text { Would not recommend- } 4(4.8 \%)\end{array}$ & $\begin{array}{l}\text { Treatment effectiveness-54(87.1\%) } \\
\text { Safety and Reliability- } 8(12.9 \%) \\
\text { Would not recommend-0 }\end{array}$ & $\begin{array}{c}\text { Pearson Chi-Square Value }=80.423 \\
\mathrm{df}=4 \\
\mathrm{p} \text { value }=.000\end{array}$ \\
\hline
\end{tabular}


Figure 1: Bar graph represents the association between the year of study and their opinion regarding the procedures in regenerative endodontic therapy. $\mathrm{X}$-axis represents the year of postgraduate study and Y-axis represents the number of participants. Following are included in regenerative endodontic procedures Scaffolds (Blue), Stem cells (Green), Growth Factors (Orange) and All of the above (Red). Most of the endodontic postgraduate students answered all the above i.e Scaffolds, stem cells and growth factors are included in regenerative endodontic procedures. Chi square test was done and the association was significant $(\mathrm{p}$-value $=0.007 ; \mathrm{p}<0.05)$

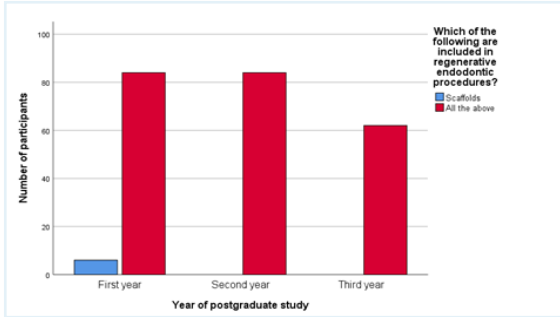

Figure 2: Bar graph represents the knowledge of first, second and third year endodontic postgraduate students about what scaffolds are. X-axis represents the year of postgraduate study and Y-axis represents the number of participants. Three dimensional porous solid biomaterials used in tissue regeneration have been indicated in Blue and dental restorative materials indicated in Red. The results were not statistically significant $(\mathrm{p}=.195 ; \mathrm{p}>0.05)$ showing that most of the students had knowledge on what scaffolds are.

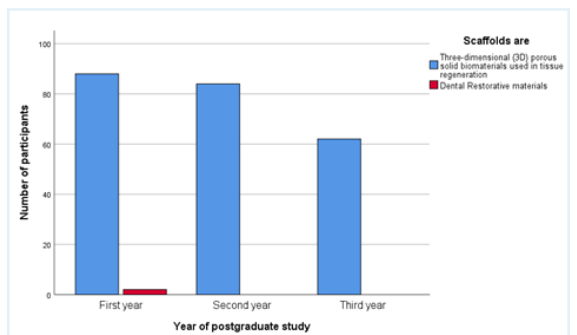

Figure 3: The above bar graph represents the method by which postgraduate students of various years gathered information about scaffolds in regenerative endodontics. $\mathrm{X}$-axis represents the year of postgraduate study and $\mathrm{Y}$-axis represents the number of participants. Based on the results, first year students acquired their knowledge by attending conferences and CDE programmes, second years through article reading and finally third years via their curriculum.

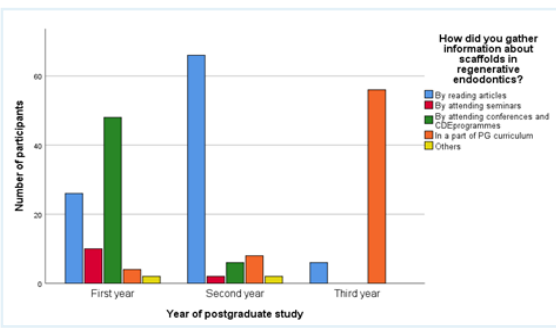

Figure 4: The bar graph represents the level of comprehension of postgraduate students about the uses of scaffold in regenerative endodontics. X-axis represents the year of postgraduate study and Y-axis represents the number of participants. According to the graph above, students of all three years selected all of the above i.e. both provide structure to a developing tissue and to allow cells to adhere, proliferate and differentiate.

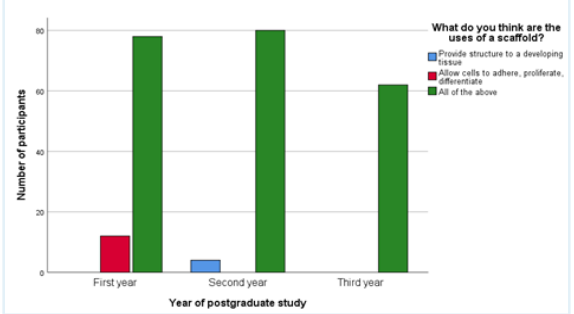

Figure 5: Bar graph portrays the insight postgraduate students have about the type of scaffold that is effective in regenerative endodontics. X-axis represents the year of postgraduate study and $\mathrm{Y}$-axis represents the number of participants. According to the graph above, students of all three years selected both i.e. synthetic and natural.

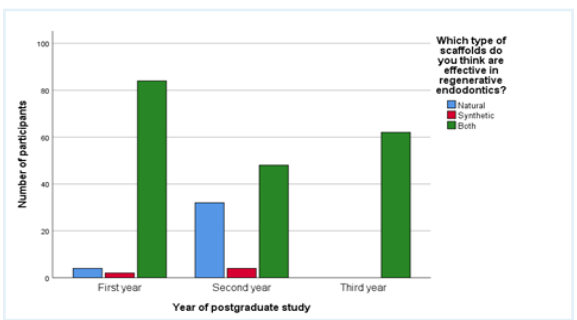

Figure 6: The achieved results from the bar graph above portrays the knowledge of postgraduate students about the role of porosity and size of scaffold in its success rate. X-axis represents the year of postgraduate study and $\mathrm{Y}$-axis represents the number of participants. The results show that a large majority of students from second and third years selected 'yes' i.e. the porosity and size of scaffold does matter in its success rate. Whereas the first years have mixed answers, with the option 'unsure' predominating.

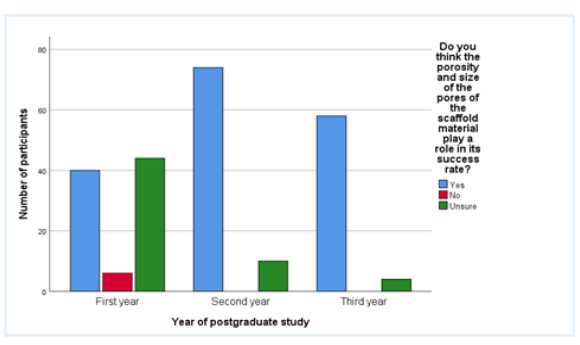


Figure 7: The question posed was to evaluate the usage of scaffolds by postgraduate students of various years. X-axis represents the year of postgraduate study and Y-axis represents the number of participants. We can conclude that neither first or second years widely utilise scaffolds in their work. On the other hand, all participating third year postgraduates have used scaffolds for regenerative endodontic procedures

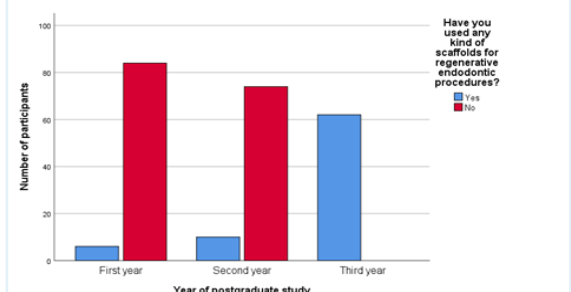

Figure 8: The bar graph above depicts the decisions of postgraduates on selecting the adequate scaffold for revascularization of necrotic immature permanent teeth with an open apex. X-axis represents the year of postgraduate study and Y-axis represents the number of participants. We can study that platelet-rich fibrin and platelet-rich plasma are common answers. First years had selected platelet-rich plasma(PRP), third years selected platelet-rich fibrin(PRF) and second years had chosen platelet-rich fibrin(PRF).

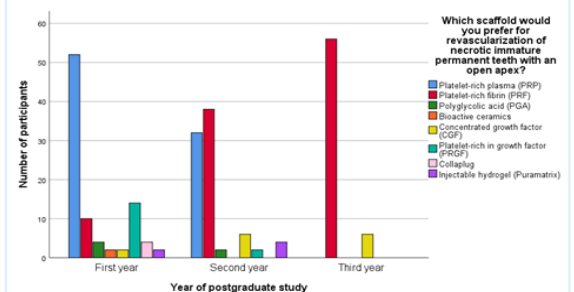

Figure 9: Bar graph represents the various decisions of postgraduate students on selecting adequate scaffold for management of a large periapical lesion. X-axis represents the year of postgraduate study and Y-axis represents the number of participants. We can conclude that most first and third years have responded with 'platelet-rich fibrin' (PRF) as their common answer, while the majority of second years have selected 'combination of platelet concentrations along with bone grafts'.

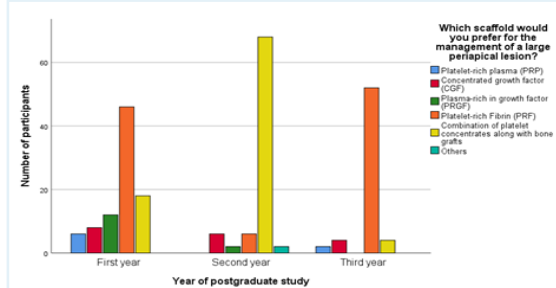

Figure 10: The above bar graph illustrates the selection of scaffold for management of periodontic-endodontic lesions by postgraduates. X-axis represents the year of postgraduate study and Y-axis represents the number of participants. It is shown that a greater part of first and second years have selected 'platelet-rich fibrin' (PRF). Most of the third years have opted 'combination of platelet concentrations along with bone grafts' as their answer.

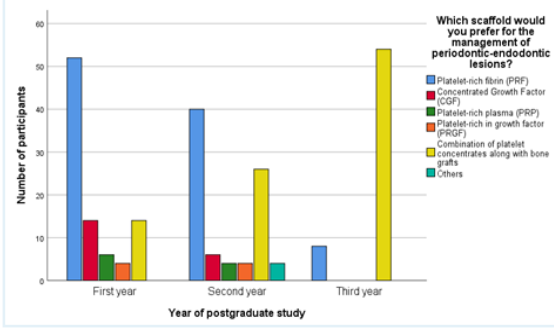

Figure 11: The above bar graph depicts the answers of students for how often they treat necrotic immature permanent teeth. X-axis represents the year of postgraduate study and Y-axis represents the number of participants. First and second years have predominantly chosen 'rarely', while third years have chosen 'sometimes' as their respective answers.

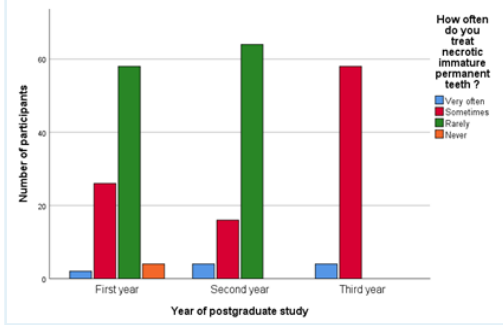

Figure 12: Bar graph represents the opinion on recommendation of scaffold to patients as a treatment option for tissue regeneration. X-axis represents the year of postgraduate study and Y-axis represents the number of participants. Majority of third year students strongly recommended scaffold as a treatment for tissue regeneration whereas first and second year students opted for maybe.

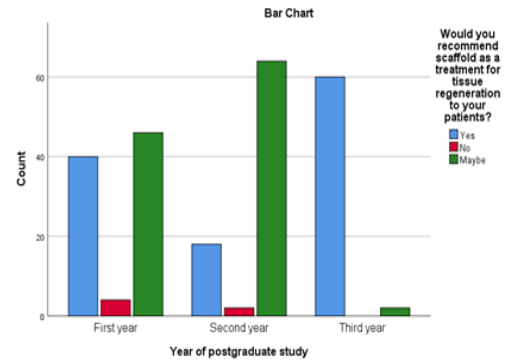


Figure 13: The displayed bar graph explains the selection of a particular advantage that would lead to the selection of the scaffold for patients by postgraduates. X-axis represents the year of postgraduate study and Y-axis represents the number of participants. The first and second years have selected 'safety and reliability', whereas third years selected ' treatment effectiveness' to treat necrotic immature permanent teeth.

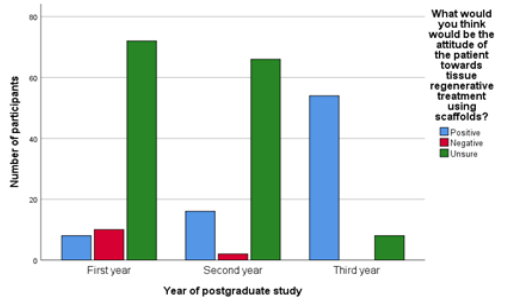

Figure 14: The bar graph displays the perspective of postgraduates on whether the high cost of the scaffolds influences patient treatment acceptability rate. X-axis represents the year of postgraduate study and Y-axis represents the number of participants. Both second and third years have mainly opted with 'yes'. First years have opted 'maybe', although there are some who selected 'yes' too.

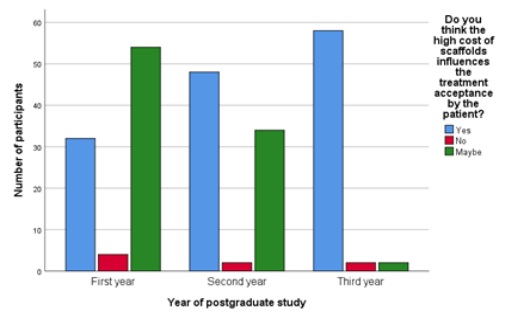

Figure 15: The bar graph represents the opinion of postgraduates on whether they would recommend regenerative procedures over dental implant therapy to patients. X-axis represents the year of postgraduate study and Y-axis represents the number of participants. A mass majority of all the years have chosen 'yes' as a common answer.

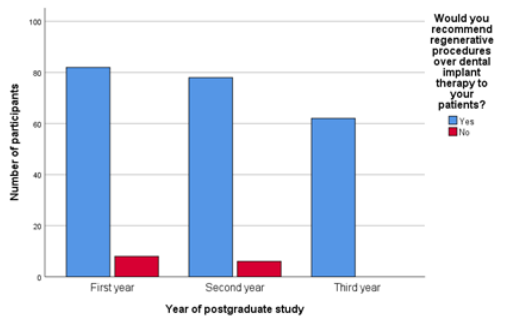

Figure 16: The displayed bar graph explains about the selection of a particular advantage that would lead to the selection of the scaffold for patients by postgraduates. X-axis represents the year of postgraduate study and Y-axis represents the number of participants. The first and second years have nominated 'safety and reliability', whereas third years have nominated ' treatment effectiveness' often to treat necrotic immature permanent teeth.

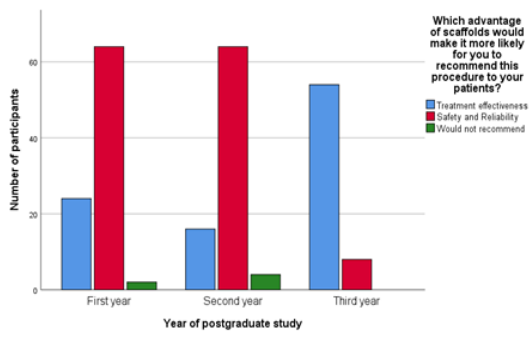

Platelet- rich fibrin was preferred by majority of first $(57.8 \%)$ and second $(47.6 \%)$ for the management of periodontal-endodontic lesion while third year students $(87.1 \%)$ preferred a combination of platelet concentrate along with bone grafts (Fig.10). First $(64.4 \%)$ and second $(76.2 \%)$ year students rarely treat necrotic immature permanent teeth while third year $(93.5 \%)$ students opted sometimes (Fig.11). Majority of the postgraduate students had a positive attitude towards recommending scaffold as a treatment for tissue regeneration to their patients (Fig.12). Most of the first $(80 \%)$ and second year $(78.6 \%)$ postgraduate students were unsure about patients' attitude towards acceptance of regenerative endodontic procedures using scaffolds while majority of third year students $(87.1 \%)$ felt that patients attitude would be positive regarding treatment using scaffolds (Fig.13). On questioning about the influence of treatment cost on treatment acceptance by patients, the majority of second (57.1\%) and third (93.5\%) students felt the high cost of scaffolds influences treatment accept- ance by patients and first year (54\%) students felt it may influence treatment acceptance (Fig.14). Majority of the postgraduate students had a positive attitude towards recommending regenerative endodontic procedures over dental implant therapy (Fig.15). The reliability of scaffold therapy was found to make it more likely to recommend scaffold therapy to patients by first $(71.1 \%)$ and second $(76.2 \%)$ year students while third year students opted for treatment effectiveness (87.1\%) (Fig.16).

The present study is a survey of endodontic postgraduate students towards regenerative endodontic procedures. It has given us a better understanding of the ethical opinions, beliefs, and judgments regarding the delivery of regenerative endodontic therapies to dental patients. The survey's findings were largely optimistic, with the majority of students agreeing that regenerative therapy could be included in dental treatments and tissue engineering will improve periapical tissue healing after nonsurgical root canal care. The marvel of Regenerative endodontic procedures is that it 
helps to clinically treat immature teeth and simultaneously aids in developing the root. It is especially helpful in the case of immature teeth that are subjected to dental caries, trauma or even anatomical anomalies. Teeth of the former sort have been treated by means of apexification wherein calcium hydroxide is placed over a significant period of time. The protocol adhered to is irrigation with sodium hypochlorite followed by placement of an intra-canal antibiotic paste. This is done without any mechanical debridement. Invoking periapical bleeding into the space of the canal which will then turn into a clot and ultimately serve as a pulp tissue scaffold that will help advance wound healing have also been suggested3. The advantage that periapical bleeding has is that blood, containing numerable platelet- derived factors, will drive fibrin scaffold, blood-derived bioactive growth factors and mesenchymal stem cells into the root canal space. This stem cell and growth factor combination will behave as a matrix for tissue engineering.

It is imperative that clinicians these days are knowledgeable and up-to-date about regenerative endodontics and its advancements to facilitate decision making for patients' treatment .

Regenerative endodontic therapies including periapical bone healing, continued root development in immature teeth, pulp tissue revitalization within a root canal, and tooth reimplantation were all valuable treatments. The postgraduate students were optimistic about the profession's future, including the incorporation of regenerative therapy and the potential benefits to patients.

The increasing number of Regenerative Endodontic Procedures (REPs), stem cell therapies, and tissue engineering articles reported in scientific journals [26], discussed at conferences, and research findings disseminated in news media was likely a key factor in the survey participants' strong general enthusiasm for the potential use of scaffolds in clinical practice. However, since most of the participants of the survey have not used any scaffolds in clinical practice, a training programme would be sufficient to encourage the use of scaffolds. Almost all of the participants agreed that scaffolds could be used in dentistry, and the majority would be able to receive through training programmes. The treatment reliability and safety of scaffolds would make the students prefer regenerative endodontic therapy. It is reasonable to assume that these students would be some of the first to be delivering regenerative therapies to their patients.

A majority of students read scientific dental journals, in their PG curriculum and by attending seminars about scaffolds to gather information regarding regenerative endodontic therapy indicating that they were well-educated in recent advancements and research in the field of dentistry.

Many of the respondents were aware of the potential therapeutic benefits of REPs and their choice of scaffolds varied among the postgraduate students for use in different clinical scenarios such as revascularization of necrotic immature permanent teeth with an open apex, for the management of a large periapical lesion and periodontic-endodontic lesions. This desire to undergo further training reflects students' support of new therapies as well as their appreciation of these therapies' ability to offer a higher level of care to their patients.

Many students, however, believed that the most significant barrier to patient acceptance of these new regenerative therapies would be their high cost. The majority of students believed that regenerative dental treatments would be a better treatment choice than dental implant therapy, and that they would be able to save teeth and dental tissues for use in regenerative dental treatments. The majority of students were willing to provide regenerative therapies. This represents students' commitment in providing their patients with the best possible care. However most of the first and second year postgraduate students have never used scaffolds in their clinical practice and Postgraduate students may find it difficult to practice these procedures more frequently due to a lack of training. The lack of enough materials to carry out the procedure may also be a major reason for not practicing. The current study results were similar to study done by [27, 28] and [29] which reflected the willingness of dentists to undergo training to practice regenerative endodontic procedures. Hence, training programmes regarding the usage of scaffolds in different clinical procedures would be efficient to encourage its use by students.

Our institution is passionate about high quality evidence based research and has excelled in various fields [15, 30-39].

\section{Conclusion}

Regenerative Endodontic Procedures have emerged as good choices for the treatment of pulpal necrosis of immature teeth. The majority of the students were aware of the characteristics of different scaffolds, allowing them to choose the most appropriate one for successful outcomes. Good knowledge and positive attitude towards the use of scaffolds were observed among postgraduate students. However, since most of the first and second year postgraduate students have not started using scaffolds in their clinical practice, a need for clinical training programmes would be efficient.

\section{References}

[1]. Gathani KM, Raghavendra SS. Scaffolds in regenerative endodontics: A review. Dent Res J . 2016 Sep;13(5):379.

[2]. Mao JJ, Kim SG, Zhou J, Ye L, Cho S, Suzuki T, et al. Regenerative endodontics: barriers and strategies for clinical translation. Dent Clin North Am. 2012 Jul;56(3):639-49.Pubmed PMID: 22835543.

[3]. Heithersay GS. Calcium hydroxide in the treatment of pulpless teeth with associated pathology. Int. Endod. J. 1975 Jul;8(2):74-93.

[4]. Rafter M. Apexification: a review. Dent Traumatol. 2005 Feb;21(1):1-8.

[5]. Andreasen JO, Farik B, Munksgaard EC. Long-term calcium hydroxide as a root canal dressing may increase risk of root fracture. Dent Traumatol. 2002 Jun;18(3):134-7.

[6]. Iwaya SI, Ikawa M, Kubota M. Revascularization of an immature permanent tooth with apical periodontitis and sinus tract. Dent Traumatol. 2001 Feb;17(4):185-7.

[7]. Lin LM, Ricucci D, Huang GT. Regeneration of the dentine-pulp complex with revitalization/revascularization therapy: challenges and hopes. Int Endod J. 2014 Aug;47(8):713-24.Pubmed PMID: 24330275.

[8]. Nakashima M. Tissue engineering in endodontics. Aust Endod J. 2005 Dec;31(3):111-3.

[9]. NYGAARD-ÖSTBY BI, HJORTDAL O. Tissue formation in the root canal following pulp removal. Eur. J. Oral Sci.1971 Jun;79(3):333-49.

[10]. Murray PE, Garcia-Godoy F, Hargreaves KM. Regenerative endodontics: a review of current status and a call for action. J Endod. 2007 Apr;33(4):37790.Pubmed PMID: 17368324.

[11]. Govindaraju L, Gurunathan D. Effectiveness of Chewable Tooth Brush in Children-A Prospective Clinical Study. J Clin Diagn Res. 2017 Mar;11(3):ZC31-ZC34.Pubmed PMID: 28511505.

[12]. Christabel A, Anantanarayanan P, Subash P, Soh CL, Ramanathan M, Muthusekhar MR, et al. Comparison of pterygomaxillary dysjunction with tuberosity separation in isolated Le Fort I osteotomies: a prospective, multi-centre, triple-blind, randomized controlled trial. Int J Oral Maxillofac Surg. 2016 
Feb;45(2):180-5.Pubmed PMID: 26338075.

[13]. Soh CL, Narayanan V. Quality of life assessment in patients with dentofacial deformity undergoing orthognathic surgery--a systematic review. Int J Oral Maxillofac Surg. 2013 Aug;42(8):974-80.Pubmed PMID: 23702370.

[14]. Mehta M, Deeksha, Tewari D, Gupta G, Awasthi R, Singh H, et al. Oligonucleotide therapy: An emerging focus area for drug delivery in chronic inflammatory respiratory diseases. Chem Biol Interact. 2019 Aug 1;308:206215.Pubmed PMID: 31136735.

[15]. Ezhilarasan D, Apoorva VS, Ashok Vardhan N. Syzygium cumini extract induced reactive oxygen species-mediated apoptosis in human oral squamous carcinoma cells. J Oral Pathol Med. 2019 Feb;48(2):115-121.Pubmed PMID: 30451321

[16]. Campeau PM, Kasperaviciute D, Lu JT, Burrage LC, Kim C, Hori M, et al. The genetic basis of DOORS syndrome: an exome-sequencing study. Lancet Neurol. 2014 Jan;13(1):44-58.Pubmed PMID: 24291220.

[17]. Sneha S. Knowledge and awareness regarding antibiotic prophylaxis for infective endocarditis among undergraduate dental students. Asian J Pharm Clin Res. 2016 Oct 1:154-9.

[18]. Christabel SL, Linda Christabel S. Prevalence of type of frenal attachment and morphology of frenum in children, Chennai, Tamil Nadu. World J Dent. 2015 Oct;6(4):203-7.

[19]. Kumar S, Rahman R. Knowledge, awareness, and practices regarding biomedical waste management among undergraduate dental students. Asian J Pharm Clin Res. 2017;10(8):341.

[20]. Sridharan G, Ramani P, Patankar S. Serum metabolomics in oral leukoplakia and oral squamous cell carcinoma. J Cancer Res Ther. 2017 Jul 1;13(3):556561.

[21]. Ramesh A, Varghese SS, Doraiswamy JN, Malaiappan S. Herbs as an antioxidant arsenal for periodontal diseases. J Intercult Ethnopharmacol. 2016 Jan 27;5(1):92-6.Pubmed PMID: 27069730.

[22]. Thamaraiselvan M, Elavarasu S, Thangakumaran S, Gadagi JS, Arthie T. Comparative clinical evaluation of coronally advanced flap with or without platelet rich fibrin membrane in the treatment of isolated gingival recession. J Indian Soc Periodontol. 2015 Jan;19(1):66-71.

[23]. Thangaraj SV, Shyamsundar V, Krishnamurthy A, Ramani P, Ganesan K, Muthuswami M, et al. Molecular Portrait of Oral Tongue Squamous Cell Carcinoma Shown by Integrative Meta-Analysis of Expression Profiles with Validations. PLoS One. 2016 Jun 9;11(6):e0156582.Pubmed PMID: 27280700.

[24]. Ponnulakshmi R, Shyamaladevi B, Vijayalakshmi P, Selvaraj J. In silico and in vivo analysis to identify the antidiabetic activity of beta sitosterol in adipose tissue of high fat diet and sucrose induced type- 2 diabetic experimental rats. Toxicol Mech Methods. 2019 May;29(4):276-290.Pubmed PMID: 30461321 .

[25]. Ramakrishnan M, Shukri M. Fluoride, Fluoridated Toothpaste Efficacy And Its Safety In Children-Review. Int J Pharm Res. 2018 Oct 1;10(04):109-14.

[26]. Hacker MC, Mikos AG. Trends in tissue engineering research. Tissue Eng. 2006 Aug 1;12:2049-57.
[27]. Epelman I, Murray PE, Garcia-Godoy F, Kuttler S, Namerow KN. A practitioner survey of opinions toward regenerative endodontics. J Endod. 2009 Sep;35(9):1204-10.Pubmed PMID: 19720217.

[28]. Das A, Nasim I. A knowledge, attitude, and practice survey among endodontic postgraduate students toward regenerative endodontic procedures. Drug invent. today. 2019 May 15;12(5): 893-896.

[29]. Manguno C, Murray PE, Howard C, Madras J, Mangan S, Namerow KN. A survey of dental residents' expectations for regenerative endodontics. J. Endod. 2012 Feb 1;38(2):137-43.

[30]. Vijayashree Priyadharsini J. In silico validation of the non-antibiotic drugs acetaminophen and ibuprofen as antibacterial agents against red complex pathogens. J Periodontol. 2019 Dec;90(12):1441-1448.Pubmed PMID: 31257588.

[31]. Pc J, Marimuthu T, Devadoss P, Kumar SM. Prevalence and measurement of anterior loop of the mandibular canal using CBCT: A cross sectional study. Clin. Implant Dent. Relat. Res. 2018 Apr 6;20(4):531-4.

[32]. Ramesh A, Varghese S, Jayakumar ND, Malaiappan S. Comparative estimation of sulfiredoxin levels between chronic periodontitis and healthy patients - A case-control study. J Periodontol. 2018 Oct;89(10):1241-1248.Pubmed PMID: 30044495

[33]. Ramadurai N, Gurunathan D, Samuel AV, Subramanian E, Rodrigues SI. Effectiveness of $2 \%$ Articaine as an anesthetic agent in children: randomized controlled trial. Clin Oral Investig. 2019 Sep;23(9):3543-50.

[34]. Sridharan G, Ramani P, Patankar S, Vijayaraghavan R. Evaluation of salivary metabolomics in oral leukoplakia and oral squamous cell carcinoma. J Oral Pathol Med. 2019 Apr;48(4):299-306.

[35]. Mathew MG, Samuel SR, Soni AJ, Roopa KB. Evaluation of adhesion of Streptococcus mutans, plaque accumulation on zirconia and stainless steel crowns, and surrounding gingival inflammation in primary molars: randomized controlled trial. Clin Oral Investig. 2020 Sep;24(9):1-6.Pubmed PMID: 31955271

[36]. Samuel SR. Can 5-year-olds sensibly self-report the impact of developmental enamel defects on their quality of life? Int J Paediatr Dent. 2021 Mar;31(2):285-286.Pubmed PMID: 32416620.

[37]. R H, Ramani P, Ramanathan A, R JM, S G, Ramasubramanian A, et al. CYP2 C9 polymorphism among patients with oral squamous cell carcinoma and its role in altering the metabolism of benzo[a]pyrene. Oral Surg Oral Med Oral Pathol Oral Radiol. 2020 Sep;130(3):306-312.Pubmed PMID: 32773350.

[38]. Chandrasekar R, Chandrasekhar S, Sundari KKS, Ravi P. Development and validation of a formula for objective assessment of cervical vertebral bone age. Prog Orthod. 2020 Oct 12;21(1):38.Pubmed PMID: 33043408.

[39]. Vijayashree Priyadharsini J, Smiline Girija AS, Paramasivam A. In silico analysis of virulence genes in an emerging dental pathogen A. baumannii and related species. Arch Oral Biol. 2018 Oct;94:93-98.Pubmed PMID: 30015217. 